УДК 821.163.09-13:398

https://doi.org/10.18485/godisnjak.2020.15.7

Ђурђина М. Исић*

Универзитет у Београду

Филолошки факултет, докторанд
Оригинални научни рад

Примљен: 15. 09. 2020.

Прихваћен: 10. 11. 2020.

\title{
ФИГУРА И ЗНАЧАЈ ГУСЛАРА У САВРЕМЕНОМ ДРУШТВУ**
}

Главна тема рада је проблем фигуре гуслара у савременом друштву, односно његов значај и улога коју има у јавном простору. Извесне промене у друшвено-политичкој и културној парадигми настале у двадесетом веку одразиле су се и на епско певање уз гусле. Према мишљењу многих теоретичара оне су довеле у питање аутентичност гусларске извођачке праксе какву познајемо данас. Стога, да би се дошло до одговора на главну тезу, најпре је истраживан развој епског певања уз гусле од предлитерарне заједнице до садашњег тренутка и забележени су сви круцијални тренуци и новине које су они увели у гусларско извођаштво. Други део рада бави се питањем традиције и културног наслеђа са филозофско-антрополошког и културолошког становишта, али и проблемима инструментализације и политизације традиције (кроз призму Бодријарове теорије о симулакрумима). У покушају да се одговори на питање какав је значај и улога гуслара у савременом друштву, сумирани су закључци до којих се дошло у овом истраживању и направљен је одређени теоријски увид - сагледавање неких од фундаменталних проблема везаних за поимање и прихватање традиције.

Кључне речи: гуслар, гусле, епско певање уз гусле, (епска) традиција, инструментализација традиције, симулакрум, култура, национални идентитет.

*iisic.djurdjina@yandex.ru

** Чланак је је настао на основу рада у оквиру мастер курса Певач и традиичја - ка поетици усмене поезије, у школској 2019/2020. години, под менторством проф. др Бошка Сувајџића. 


\section{1. Увод}

Место које епско певање уз гусле заузима у савременом друштву у тесној је вези са другим аспектима друштвеног живота. Културни живот и културна политика, одређена идеолошка усмеравања друштва и владајући друштвени поредак, економски и проблеми свакодневице, утицај популарне културе и медија, довели су до опадања интересовања за гусле код најширег слоја друштва. Комерцијализација која је захватила домен културе, губљење природне и стварање вештачке аутентичности у уметности, доминација информационих технологија и система мишљења базираног на прикупљању информација, конзумеризам и култура потрошње, површна и лака забава популарне културе, али и обескорењивање народа у процесу глобализације, допринели су томе да целокупна традиција буде или скрајнута на маргине јавног културног живота или подвргнута пародизацији до мере када губи сва своја иманентна својства, своју суштину, и претвара се у персифлажу.

Корени масовнијег дистанцирања од (епске) традиције сежу до самих почетака двадесетог века. Извесне промене у друштвено-политичкој и културној парадигми које су се већ тада почеле догађати, одразиле су се и на епско певање уз гусле. Према мишљењу одређене групе теоретичара оне су довеле у питање аутентичност гусларске извођачке праксе какву познајемо данас. Крајњи производ оваквог становишта јесте радикална проблематизација епског стваралаштва и целокупне традиције у савременом тренутку. Појављују се две „зараћене стране”: космополитски „негатори” традиције и њени „слепи” чувари. Истина је, као и увек, негде на средини. Трагајући за њом, доћи ће се и до одговора на главно питање којим се овај рад бави.

2. „Аутентични” певач прича - контекст епског певања уз гусле и фигура гуслара у склопу усмене епике ранијих, предлитерарних времена

У литератури преовлађује став да се епско певање уз једноструне гусле $^{1}$ појавило и одомаћило у динарској области, у расејаним сеоским заједницама које је настанило српско становништво после турских освајања средњовековних држава. Патријархалност као друштвено уређење и очување наслеђа, као духовне вертикале, били су темељ опстанка који је сваки

${ }^{1}$ Поред једноструних, постоје и двоструне гусле, које су знатно ређе, а махом су карактеристичне за пределе западне Босне и Лике. 
члан заједнице прихватао још од најранијих дана свог живота (путем тзв. „народне педагогије”), а који је за гуслара био детерминишуће својство.

За чланове ове заједнице гусле су представљале својеврсну светињу: уједињујући елемент друштва, који их „спаја са кореном” и на тај начин осмишљава њихово постојање, био је неписани уџбеник историје који будућим генерацијама оставља у аманет и сећање најважније тренутке и догађаје из прошлости те заједнице, пружајући поруке наредним поколењима како да се сами сачувају од искушења на која ће наићи (Сувајџић 2010: 181$)^{2}$.

Када је реч о усменој епској песми, која се изводи специфичним певањем уз гусле, Алберт Лорд је дефинише као „приповедну поезију састављену на начин који су кроз многе нараштаје развијали певачи прича, не знајући да пишу; он се састоји у грађењу метричих стихова и полустихова посредством формула и формулних израза и грађењу песама коришћењем тема" (Лорд 1990 I: 21). Формуле, као традиционални елементи усмене епике, помажу епском певачу да у току самог усменог извођења, дакле у великој брзини, ствара песму. Међутим, формулативност епске поезије не подразумева шаблонизованост и „окошталост”. Формуле су флексибилне: „способне за промену и заиста често производе друге и нове формуле" (Исто, 22), што епском певачу гарантује велику слободу приликом коришћења: могућност да све своје тренутне замисли изрази путем већ устаљених основних образаца формулативности.

Какав је однос традиције и идивидуалног талента у контексту епског певања уз гусле? Да ли већ установљена начела грађења песме укидају сваку могућност индивидуалног израза? Лорд каже да није тако. Премда традиционални стил игра велику улогу, из сваке епске песме просијава индивидуални стил певача прича: „Сви певачи користе традиционалну грађу на традиционалан начин, али никада два певача не користе потпуно исту грађу на потпуно исти начин. Традиција није сачињена по једном калупу" $($ Исто, 118). Епски певач је зато и отелотворење традиционалног и оригинални стваралац.

Индивидуалност се огледа и у самом инструменту: сваки се инструмент прави посебно за сваког извођача, штимује се према боји његовог природног гласа и тонској висини: „Може се рећи да су [гусле] индивидуализоване за гусларе" (Радовановић 2000: 60). Није постојала јединствена техника певања уз гусле, што је остављало додатног простора за индивидуална обележја усмене епике: извођачи су се разликовали

${ }^{2}$ Треба истаћи податак да су гусле најчешће прављене од јаворовог дрвета, које је у претхришћанској традицији словенских народа било везивано за култ предака. 
„према томе како извијају своје мелодије, кроз коју школу пролазе, којим гласом певају” (Сувајџић 2010: 185). На овај начин стварана, свака епска песма била је мала и непоновљива креација певача прича. Када је реч о карактеристикама самог инструмента, важно је истаћи и то да гусле карактерише специфичан распоред тонова који не наликује ни једној од данашњих стандардних музичких скала.

Поред овладавања традиционалним средствима, епском певачу је потребан и таленат који ће епску песму „оживети”. Међутим, тај таленат мора бити друштвено прихваћен, јер у противном неће „пустити корење” у друштвеној средини за коју се епска песма у првом реду и ствара. Дакле, постоји међусобна условљеност певача и колектива. Сам чин извођења епских песама, као првенствено оживљавање прошлости (херојско-митолошке или недавне) стога подразумева изузетно сложен сплет две групе елемената: контекстуалних/синхроних елемената (извођач, текст, публика, контескт извођења, шири контекст - политички, друштвени, идеолошки итд.) и дијахронијских елемената, везаних за корпус традиције и активирање механизама ,асоцијација на различите слојеве традиције и претходеће извођачке ситуације" (Ђорђевић Белић 2017: 40).

Када се пак говори о индивидуалном доприносу који певач уноси у процес стварања песме, још је Вук уочио да неки певачи по том критеријуму надмашују просек. Тако, између осталих, издваја Тешана Подруговића, старца Милију, старца Рашка, слепу Живану и др. Међутим, придавање превелике пажње тзв. „гусларским звездама” отпочело је тек у првим деценијама двадесетог века. Од свих Вукових певача само је Филип Вишњић стекао посебан култни статус у званичној епској традицији, само је он постао први симбол фигуре гуслара, односно „национални епски бард”.

Публика представља друштвено-културни елемент идентитета гуслара и један је од кључних чинилаца у процесу комуникације ритуалног типа ${ }^{3}$, као основне функције извођења епских песама. Претпоставка је да сви чланови заједнице који учествују у оваквом виду комуникације деле исти или сличан вредносни и културни систем. У периоду предлитерарне усмене епике, диференцијација извођач-публика није била тако стриктна. Дешавало се да су у току једног извођења гуслари постајали део публике, а већ у наредном извођењу одређени појединци из публике постану и

${ }^{3}$ У синхронијској димензији, комуницирање путем извођења епских песама одвија се хоризонтално, у самом физичком простору (између извођача и публике, али и извођача са самим собом), док се у дијахроној димензији комуницирање одвија вертикално, са неком вишом инстанцом (божанство/преци), чинећи вид колективног памћења, односно трансмисије - очувања порука, а са њима и самог друштва у темпоралној димензији постојања (Лајић Михајловић 2014: 39, 127). 
сами извођачи епских песама. Циљ је био да се читава заједница уједини у јединственом емоционално-мистичном стању које настаје првенствено као резултат извођачке делатности самог гуслара.

Аудиторијум је био критички суд, односно „оштра цензура” свему што извођач изнесе у јавни простор. Публика је процењивала врсту и квалитет гусларевог репертоара (степен подударности са очекиваним корпусом знања епског наслеђа), као и његове извођачке (вербалне, музичке и изражајно-драмске) способности (Исто).

Са развојем друштва мењао се и састав публике: од релативно хомогених мањих група племенских, патријархалних заједница, до еклектичних и хетерогених група, које се појављују већ у двадесетом, а пуну експанзију достижу у двадесет првом веку. Међутим, однос публике и извођача никада није био у потпуности реципрочан, чак ни онда када је у питању било извођење епских песама у племенском друштву, где је мала бројност публике погодовала представи о епском извођењу као некој врсти разговора у коме су сви чланови равноправни ${ }^{4}$. Аудиторијум је увек подређенији и пасивнији актер комуникације, који има ограничено поље утицаја на самог извођача и процес стварања и обликовања епске песме у току извођења, мада је тај утицај у одређеном, и не баш увек позитивном, смислу постајао све већи са променама које су се догодиле у двадесетом веку.

\footnotetext{
${ }^{4}$ Ипак, извођење у оваквим околностима омогућавало је одређену врсту квалитетније повратне информације људи окупљених око извођача, била она вербална или невербална: „Слике са терена, из крајева у којима је првих деценија 20. века била још добро очувана патријархална култура, сведоче да присутни слушају гуслара врло пажљиво, нарочито ако је добар, а да је експресивност и сугестивност извођења умела да занесе слушаоце 'да занеме и заплачу'. О усмерености пажње публике на информативну вредност епске песме и потенцирање њене хроничарске димензије говоре подаци да се шапатом, жагором, гласним исправљањем и негодовањем, па и демонстративим напуштањем седељке, реаговало на претеривања или неистину коју би у песми изнео гуслар" (Лајић Михајловић 2014: 133). Стога се може рећи да је слушалац у овом периоду имао прилично активну улогу у процесу комуникације.

С друге стране, због чињенице да су живели у разбацаним планинским сеоским насељима, у којима су куће километрима удаљене једна од друге, људи су често у различито време долазили на извођења епских песама уз гусле и одлазили са њих. Због тога је састав ове публике врло често био променљив, а и сама публика је често бивала нестрпљива. То је све утицало, како на сам начин извођења, тако и на његов ток, па се зато неретко дешавало да се варијанте једне песме, чак и код истог извођача, разликују највише по свом крају (Лорд 1990 I: 44). На стандардизацију извођења краћих одломака, а са њом и скраћивање пажње публике, касније су у великој мери утицали гусларски концерти и такмичења (Лајић Михајловић 2014: 134).
} 


\section{3. Иновације у усменом епском певању уз гусле: квалитативна/квантитативна побољшања, очување епског наслеђа или његова смрт?}

Кључну новину у извођењу епских песама уз гусле, како на плану ширења тескта, тако и на плану самог начина епског стваралаштва, направиле су штампане песмарице народних епских песама, посебно песмарице Вука Караџића. Промене су се односиле на образовни статус певача, проблеме варијантности текстовног предлошка, а дошло је и до измене правца усмерености стваралачког потенцијала гуслара-извођача са инвентивности на плану текста, ка инвентивности на плану музичког израза (в. Лајић Михајловић 2012: 123). Песмарице су својим иновацијама само покренуле талас новина како на плану усменог епског извођења уз гусле, тако и на плану саме (епске) традиције. Тај се талас протезао кроз цели двадесети век.

Почетком двадесетог века, однос према традицији и наслеђеним структурама на свим пољима људског деловања почиње да се проблематизује. Ако су ствараоци периода модерне још и успевали да се одрже у наслеђеним оквирима, први талас радикалног отклона од традиције догодио се двадесетих година двадесетог века, у време авангарде. Авангарда доноси са собом ново време које обележавају перманентна акција и живи дух. Потребно је било унети свежину, покидати све окоштале логичке споне и фразе, све превазиђене и у основи мртве системе и наслеђене структуре, а затим пружити нова значења, конструисати нове програме, нову естетику, и пронаћи нову вертикалу између човека и Космоса.

Као опште место целокупне авангарде јавља се јасно наглашавање дистинкције између старих и младих, било у форми потпуног раскида, било кроз само делимично признање заслуга ствараоцима пређашњих епоха. Оно што је спајало писце и критичаре различитих покрета у оквиру авангарде био је радикални антитрадищионализам. Циљ је био срушити стари свет, његове мртве институције и његову јаловим фразама оковану културу, да би се на месту тих рушевина подигао нови живи свет, нове институције и нова култура која у пуној мери и на свеж, до тада невиђен начин, осликава човекову душу.

Оваква струјања и промене парадигми у културним и друштвеним круговима подстакла су и преиспитивање односа према самом епском наслеђу и пракси гусларског извођења. Збуњеност и недоследност, па и опречни ставови када је у питању однос према традицији у првој половини двадесетог века, захватала је све кругове друштва без обзира на степен образовања (в. Лајић Михајловић, Ђорђевић Белић 2016: 205). Тај однос 
се кретао од аутоматског и безрезервног прихватања наслеђеног архаичног извођења, до потпуно авангардних новина на том плану и њиховог некритичног/помодног примања. Било је, додуше, и извесних „умерених струја” које, и поред става да неке архаичне елементе треба избацити, ипак нису оберучке прихватале све драстичне новине новог века, већ их је одликовало „свесно залагање за очување традиционалних мелодијских слика" (Лајић Михајловић 2014: 111). Време после Великог рата је време у којем нема места за хероје, па је стога и улога „епског барда” у великој мери проблематизована и обујмљена велом идеологизације, која је, пре свега, захватила сам репертоар гуслара. ${ }^{5}$

Принцип „ауторства” постаје доминантан: гуслар сада пише текст, не ствара га током извођења (премда у прво време текст још увек није бивао дословно меморисан), а почињу и да се раздвајају аутор текста и аутор музике. Уместо песама у целини, све више се изводе само одломци. Гусле сада праве за то посебно обучени мајстори, што доводи до извесне „деперсонализације” овог инструмента. Гусларско извођаштво се развија у правцу професионализације, коју неминовно прате и комерцијализација и (нужно са тим) деепизација, као и разводњавање епских вредности. Мења се и начин дистрибуције и рецепције епских песама, за шта су одговорни нови медији и различити носачи звука. ${ }^{6}$ Ипак, највеће промене дешавају се у изласку гусларског извођења из (релативно) интимног простора у јавни простор, чиме се у великој мери губи ритуална компонента самог извођења, а однос са публиком постаје све дистанциранији. Тај се искорак догодио најпре на гусларским такмичењима. ${ }^{7}$ Њих су пратили: идеологизација, тесне везе са фигурама моћи и политичким правцем у коме се кретала земља, известан ступањ сензационализма, промене у самом извођењу епских песама уз гусле, стављање акцента на перформативни карактер извођења, упитност поводом стручности жирија и регуларности жирирања, појава римованог десетерца, рађање „гусларских звезда” и

\footnotetext{
${ }^{5}$ Идеологизација се огледала у пропагандном карактеру репертоара неких гуслара, у коме су величане идеје југословенства, а касније и партизанског покрета. Гуслар је тако, поред улоге чувара традиције, добио и нову улогу: оног који у епици овековечује догађаје из блиске прошлости (в. Ђорђевић Белић 2017: 68). Овде се већ назиру клице неотрадиционализма: уз помоћ ауторитета који има наслеђе, легитимизовати „оно ново које се тек успоставља" (Наумовић 2009: 18), процеса који ће крајем века имати озбиљне последице по друштво, али и по само епско наслеђе.

${ }^{6}$ У том смислу, праву револуцију донеле су грамофонске плоче. Више о овом феномену у Лајић Михајловић, Ђорђевић Белић 2016, Лајић Михајловић, Ђорђевић Белић, 2017 и Лајић Михајловић 2012.

${ }^{7}$ Више о тзв. „гусларским утакмицама” и гусларској такмичарској пракси у двадесетом веку видети у Лајић Михајловић 2011 и Лајић Михајловић 20146.
} 
хероизација њихових биографија, ${ }^{8}$ процват постфолклорних жанрова, ${ }^{9}$ промене у структури публике, као и промене у односу међу актерима оваквог облика комуникације..$^{10}$ Што се тиче рецепције, све већа присутност грамофонских плоча (касније и других носача звука, а потом и развој медија $^{11}$ ) доводи до стриктније диференцијације извођач: аудиторијум

${ }^{8}$ Године 1920. појављују се на овим просторима прва филмска критика и први теоријски оглед о филму, два рада настала из пера једног књижевника - Бошка Токина. У то доба код нас још увек постоји сумња у уметнички потенцијал филма. Један од разлога за тако негативне оцене седме уметности сигурно је била и појава прављења извесног „култа личности” од појединих глумачких имена, која су често била главна „реклама” за пласирање неког (неретко осредњег) кинематографског остварења. Ову појаву Токин је окарактерисао као доминацију „стар система” и против ње се оштро бунио, као против извитоперења уметности која у основи, како је сам веровао, има хуманистички карактер.

С друге стране, изражена гусларска такмичарска пракса, довела је до многих промена, неретко отелотворених у форми девијација усмене епске традиције. Једна од таквих била је и изразита индивидуализација гуслара-извођача, који су се уздизали до статуса „гусларских звезда”. Тако су филм, као најмлађа уметност, која је још била у фази настанка и дефинисања, те стога често виђана као најобичнија кловнерија недостојна озбиљније пажње, и традиција усменог извођења епских песама уз гусле, као корпус наслеђа хероизиране прошлости, чији корени сежу све до архаичних, најстаријих, митских слојева људске свести, парадоксално, грцали под истим теретом - теретом владавине „стар система”.

Једна од таквих „гусларских звезда” био је Петар Перуновић Перун, „гуслар који је поред општег имао и музичко образовање” (Лајић Михајловић 2014б: 402). Његово место у традицији извођења усменог епског песништва уз гусле није тако једноставно одређено, као што је случај са његовим славним гусларским претком, Филипом Вишњићем. Иако су прављене извесне аналогије између њих двојице, Перун ипак није у колективном сећању званичне (над)националне културне традиције остао тако чврсто упамћен као слепи гуслар Устанка. О фигури Петра Перуновића Перуна, али и других „гусларских звезда” више у Лајић Михајловић 2014б, Ђорђевић Белић 2017 и Лајић Михајловић 2013.

${ }^{9}$ Проблем који се појавио са променама које су захватиле традицију епског певања уз гусле, а који се највише одразио на аспекат савременог гусларског репертоара, тиче се превасходно ауторских текстова. Они су, као што је представљено, не налазе сасвим ни у домену усмене културе (тешко се данас може пронаћи случај да гуслар у тренутку извођења ствара песму), али ни у домену писане културе. Различите околности довеле су до оваквог „разилажења": историјски тренутак настанка текста, промене у културној и социјалној парадигми, промене на политичком и идеолошком плану, пораст значаја индивидуалног аспекта ауторске поетике (укључујући овде и присуство ауторских коментара у епским хроникама, најчешће у оквиру контекстуалних формула, у којима аутор износи своја објашњења опеваних догађаја, али и своје идеолошко-политичке ставове), промене у структури аудиторијума и врсти односа који се успоставља међу актерима оваквог комуникационог процеса, промене у дистрибуцији и начину посредовања гусларских извођења и сл. Више о феномену постфолклора видети у Варшавер 1991, Ђорђевић Белић 2016 и Ђорђевић Белић 2017.

${ }^{10}$ Детаљније о новинама на плану структуре аудиторијума, рецепције епског стваралаштва и односа међу актерима комуникационог процеса у Лајић Михајловић 2014.

${ }^{11}$ Телевизија је, као уосталом и други медији и остали видови средстава масовне комункације, допринела унификацији усмене фолклорне традиције, укидању регионалног карактера и уклапању у глобалистичке токове којима се креће модерно друштво. Један од императива који се са енормном експанзијом масовних медија појављује у популарној култури јесте 
у оквиру епског певања уз гусле: тачно је одређено ко је извођач, а ко публика, и ту не може бити никаквих размена (као што је то био случај у традиционалној извођачкој пракси). Притом, појавила се и реална опасност од пасивизације публике, која, у најгорем случају, постаје обичан конзумент. Тиме се овакав комуникациони процес, у крајњој линији, своди на псеудоинтеракцију. ${ }^{12}$

\section{4. Између националног и глобализма - фигура гуслара као симбол традиције и културног наслеђа}

Дијаметрално поимање традиције, али и целокупног културног наслеђа, има своје корене у нерешеном „сукобу” између просветитељског и романтичарског схватања традиције и односа према њој. Према просветитељском схватању (чији је најизразитији представник Кант са својим императивом о изласку из самоскривљене незрелости), традиција је (као сублимација незнања, предрасуда, слепе догматичности, различитих врста нетрпељивости, социјалне и сваке друге врсте неједнакости) главни узрочник застоја људског развоја и непријатељ људских слобода. С друге стране, филозофска мисао романтизма (са важним представницима у Хердеру и В. Хумболту), приписује појму позитивно значење, уздижући

феномен „изузетости”, одскакања од просека, „,аутентичности”, често и до искарикираних и извитоперених граница, када прелази у сензационализам. Староримска „политика” хлеба $u$ игара оживљава у модерном добу и попут вакуума усисава у себе све, чак и традицију, која се потом, у свом травестираном облику, пружа гладним масама.

${ }^{12}$ Момчило Настасијевић се бави овим проблемом у својим есејима За хуманизацију музике и Против машинизаиије уметности. Окосницу његовог размишљања чини проблем отуђења, као последице човековог односа према раду у „машинизираној стварности”. На трагу Русоове мисли, он позива на окретање од цивилизације и напретка који је човека и довео у стање отуђености и одузео му његову целовитост. Настасијевић поставља човека у средиште ствари. Матерња мелодија више није израз, већ мост према другима, средство за истинску комуникацију „када се чини да више нема куд.” Машинизација уметности нарушава његову замисао о извесној светости чина усмене комуникације између стваралаца и прималаца, а штетна је и за дух јединке. Примера ради, слушање грамофонске плоче, иако удобно, заправо је погубно по човеков дух. Он се тада, како примећује овај аутор, постиди од онога што је сам до тада створио. У том тренутку почиње мртвило духа. Ствара се елитна мањина која је одрођена, она намеће нову врсту „немелодиозне мелодије”, „духом утрнулој цивилизованој маси.” Обнову Настасијевић види не на Западу, већ код нас, јер је овде сачуван „живи искон” примитивне народне мелодије. Уколико је у есеју За матерњу мелодију Настасијевић ишао унапред, тражећи наш аутентичан израз на путу ка великим културама, у есеју За хуманизаиију музике он се враћа уназад, у примитивни стадијум постојања, где је важио примат усмене комуникације и непосредне заједнице примаоца и ствараоца, и где је постојала она целовитост која је сада изгубљена. Дијалог са другима има смисла само ако доприноси укорењивању у своме, у супротном, треба га одбацити (в. Настасијевић 19916 и Настасијевић 1991в). 
га на метафизички ниво: традиција постаје отелотворење „духа народа”. Овакво схватање се одржава и даље развија и током двадесетог века. Тако ће Хари Левин у предговору Лордовој књизи Певач прича указати на то да традицију треба посматрати из другачијег угла, „не као инертно прихватање окамењеног корпуса тема и конвенција, већ као органско стање поновног стварања онога што је примљено и што се предаје даље" (Лорд 1990 I: 11; курзив Ђ. И.). Традиција постаје когнитивни оквир за формулисање наратива који се потом преносе у оквиру одређене друштвене групе. Међутим, рационалистичка схватања просветитељства никада нису била у потпуности уклоњена, тако да и у савременој теоријској мисли просветитељски антитрадиционализам има и даље великог удела. ${ }^{13}$

Преношење традиционалног садржаја није механички, већ активан процес: свака нова генерација бира и изнова интерпретира елементе традиције која се преноси. У овоме лежи опасност од њене злоупотребе и инструментализације, најчешће у политичко-идеолошком смислу, која је на просторима бивше СРЈ кулминирала крајем друге половине двадесетог и почетком двадесет првог века, у виду њене радикалне злоупотребе и (политичке) инструментализације:

Стварајући симболичку везу између а) политичког актера, b) прошлости групе која се по правилу замишља као „света” или „славна” и с) осећаја идентитета групе, традиција функционише као користан медијум легитимизације стварних или фиктивних намера политчких актера. Укратко речено, традиција се овде поглавито посматра као више или мање свесно креирано симболичко средство, чије употребе више зависе од интереса оних који је инструментализују него од њених интристичких својстава (Наумовић 2009: 14; курзив Ђ. И.).

Последице овакве употребе традиције, односно својеврсног демагошког „поигравања” са њом, веома су озбиљне како по друштво, тако и по саму традицију. Однос који влада између дате традиције и производа одстрањивања иманентних својстава те традиције у оваквом дискурсу, идентичан је оном односу који влада између стварности и феномена који Бодријар назива „симулакрумом”.

Појам „хиперстварности” тесно је повезан са концептом симулакрума и означава копију или слику која нема референтни оригинал. Жан Бодријар тврди да би хиперстварност била крајњи стадијум симулације: знак или слика немају више никакве везе са објективном, референтном

${ }^{13}$ Више о овом сукобу, али и о тешкоћама дефинисања појмова „традиција” и „наслеђе”, о односу традиције и идентитета, о блискости појмова „традиција”, „историја” и „култура”, о типовима друштвених група у којима долази до процеса преношења наслеђа видети у Наумовић 2009. 
стварношћу, већ постају сопствени симулакруми. Знакови почињу да се разумеју насупрот једно другом, смисао се креира кроз разлике међу њима (А је А зато што није Б), а не насупрот некој објективној стварности на коју реферирају. Производња се одвија тако што знакови производе друге, нове знакове.

Када је реч о употреби или инструментализацији традиције (која се неретко одвијала у склопу њене институционализације), она се јављала у периодима различитих друштвено-културолошких и/или политичко-идеолошких промена, најчешће у склопу (нео)традиционалистичке политичке реторике. ${ }^{14}$ Коришћење плански одабраних елемената традиционалног корпуса (најчешће вредносних система и симбола), издвојених из свог природног контекста и очишћених од иманентних својстава и сврхе постојања, а зарад постизања (политичких) циљева који су у несагласју са природом тих елемената, јесте управо инструментализација традиције. Појава, порцес или личност која се жели на овакав начин легитимисати доводи се у (реално неосновану) везу са одабраним елементима традиције, при чему се позитивни аспекти одабраних елемената приписују тој појави, процесу или личности. То се може осликати следећим логичким силогизмима:

Скуп А је врховни ауторитет са позитивним, „светим” својствима $\rightarrow$ Скуп Б је део скупа А $\rightarrow$ дакле скуп Б има позитивна, „света” својства

\section{аналогно томе:}

Скуп В је „као” скуп Б $\rightarrow$ Скуп В је део скупа А $\rightarrow$ дакле скуп В има позитивна, „света” својства.

Кроз историју су владајући политички кругови, без обзира на идеолошка усмерења, у различитом степену користили традиционалистичку реторику као извор легитимитета своје власти, али крајем двадесетог века (а то се наставља и у двадесет првом веку) традиција се политизује на све бескрупулознији и перфиднији начин, тако да понекад поприма и гротескно-карневалски карактер.

${ }^{14} \mathrm{O}$ условима за појаву праксе употребе традиције у политичке сврхе, али и о главним политичким циљевима такве употребе традиције видети у Наумовић 2009: 156. Инструментализација је тесно повезана са митоманијом. Овај аутор дефинише три кључна мита политичког наратива насталог инструментализацијом традиције крајем двадесетог века на простору $\mathrm{Cp}$ бије: мит о златном добу средњег века, мит о историјском паду и мит о националној обнови. Међутим, како и аутор сам закључује, иза ових митова није се крио никакав истински обновитељски полет, већ су они пре били параван за остварење прикривених политичких циљева. 
Политичка злоупотреба традиције није заобишла ни гусле. Самом природом теме свога певања (о великим јунацима), епско певање уз гусле одувек је било предмет занимања инстанци моћи и власти. ${ }^{15}$ У политичком дискурсу у Србији крајем двадесетог и почетком двадесет првог века, оформиле су се две супарничке политичко-идеолошке струје. У сфери таквих збивања, гусле су се појавиле као круцијални елемент националног идентитета за припаднике „,аутентичне”, „,историјске” и „патриотске” Прве Србије, и елемент заосталог менталитета за припаднике „европске”, „космополитске” и „грађанске” Друге Србије. Искључивост и самодовољност обе стране огледа се у чињеници да се њихово постојање темељи управо на суштинској и радикалној негацији оне друге стране и свега што она заступа (А је А зато што није Б). У вихору њихових међусобних сукоба истинска природа гусала и њихов значај у корпусу традиције (као референтни оригинал, уколико се послужимо бодријаровском терминологијом) остали су без пажње коју заслужују. Гусле се сматрају или „српским јеванђељем” (у склопу реторике која популистичком и звонком формом излагања покушава да прикрије недостатак суштинског и дубоко утемељеног разумевања) или регресивним елементом и симболом латентних шовинистичких и фашистичких тежњи. Обе карактеризације немају никакве везе са правом природом гусала. У савременом тренутку, политизацијом епског певања уз гусле, овај инструмент (а са њим и гуслар-извођач) губи своју најважнију одлику - фактор уједињења - и претвара се у своју супротност: постаје симбол поделе становништва на простору бивше Југославије.

У трагању за одговором на питања - какав је положај гуслара у савременом друштву, у чему је и колики је његов значај и која је његова улога, неопходно је позабавити се и стањем у култури у нашој земљи и местом које елементи традиције заузимају у њој. А стање у култури је веома лоше. Вишедеценијско тенденциозно урушавање свих културих вредности, агресивна пропаганда псеудокултуре и, у крајњој линији антикултуре $^{16}$, суштинско обескорењивање и псеудоутемељивање у традицији,

${ }^{15}$ Постоје подаци да је још кнез Милош волео да гусла и да је окупљао гусларе да му свирају, али да је забрањивао песме у којима се опевају Први српски устанак и противничка династија Карађорђевића (Сувајџић 2010: 186).

${ }^{16}$ Кампање владајућих инстанци деведесетих година прошлог века и прве деценије овог века, у којима се промовише култура и културно понашање, својом фрагилношћу нису могле направити већег одјека борећи се са буком и агресивношћу некултурне пошасти. Изостајали су тада, као и данас, јасније утемељен и чвршће дефинисан културни систем и културна политика, па се све сводило (опет, као и данас) на „герилске” побуне и наступе културно освешћених појединаца и група. Одговорни као да заборављају да без културе нема ни народа у правом смислу те речи - људи без културе обична су маса без духа и слободне мисли. Или је можда некоме управо то и циљ? 
погодовали су процесу бестијализације и дехуманизације човека, што је кулминирало феноменом „ријалити шоу програма”, којим бодријаровска хиперстварност добија одурно-карневалске карактеристике и, у својој суштини, приближава нас атмосфери хорор-научне фантастике:

У „ријалити” шоу програмима на делу је смишљено провоцирање човекове радозналости које се покушава остварити приземним опонашањем живота, непримереном колоквијалношћу и опсценом простотом. Тријумфују баналност и кич као носиоци квазиуметничких културних садржаја. Девијаџија људскости, која је непосредством камере видљива и тиме доступна свачијем оку, врши се у име (изгубљене) људскости. Она је узрокована покушајима надомештавања непосредности и блискости коју индукује жива комуникација међу људима. Оваквим шоу-програмима девастирају се и човек и медиј. Медиј у покушају да досегне људску (у бити усмену) животност и непосредност, човек у покушају да се медијски препакује и прода као комериијално прихватљив производ. „Ријалити” шоу програм представља врхунац глобалне медијске хипостазе празнине, бастард свеопште и (не)достижне пројекције жеља милиона, форматизован у медијско-маркетиншки избрушеном облику. Он човеку даје кич уместо илузије. Даје му лажну стварност уместо привида. У бити, даје му све што има зато што не поседује ништа (Сувајџић 2010: 180; курзив Ђ. И.).

С друге стране, актуелан је процес обескорењивања народа. У извесним телевизијским шоу програмима који, иронично, имају за циљ очување и промоцију националне традиције, на делу је заправо њена травестија, пошто је забава главни императив. Истовремено долази до укидања емисија које негују прави дух традиције. Додуше, такве емисије се још увек могу наћи на станицама Радио Београда, али су слушаоци оваквих програма махом из редова високообразоване публике чији се глас, у оваквом поретку ствари, на јавној сцени слабо чује и нема готово никакав одјек у ширим круговима друштва. Највеће народно благо постаје тако саставни део живота одређене интелектуалне елите, док се остали потомци народа који је то благо стварао махом даве у празној, обездуховљеној и претенциозној антикултури, до те мере да њихово биће истинску народну традицију све мање распознаје и доживљава као своју. Због свега тога, када је реч и о гуслама, које чине важан део народног блага, прилике су веома тешке. Скрајнуте на маргине културне сцене, препуштене су само истинским посвећеницима и заљубљеницима, док је њихова суштинска вредност остала непозната већем делу народа. Некима су гусле у извесној мери чак и одбојне, друге нагоне на подсмех и поругу, трећима су симбол кочења прогреса итд. А судбина гуслара у савременом друштву идентична је судбини њиховог инструмента.

Каква је улога традиције у култури једног народа и конституисању његовог идентитета? Каква је улога гуслара као симбола те традиције? 
Да ли су промене које су захватиле епско певање уз гусле у двадесетом веку довеле до потпуног раскида са суштином тог певања у мери да га треба потпуно занемарити? Где је место традиције у домаћим, европским и светским оквирима? Да ли се зарад светле и хумане будућности треба одрећи своје традиције? Да ли се, услед губитка духа и вере у Апсолутно Добро, треба помирити са нихилизмом и препустити инферналном ништавилу у коме се налази савремена цивилизација? Ако прихватимо премису да је микрокосмос одраз макрокосмоса, да бисмо одговорили на претходно постављена питања, морамо поћи од човека као појединца и његове субјективности.

Свако ко се у неком тренутку макар имало замислио над животом, сигурно је схватио да у њему постоје два света која су у симетричном односу: спољашњи свет објективне датости и унутрашњи, субјективни свет. И док је скоро потпуна спознаја објективног света, као могућност, дата свима у виду очигледности, дотле је спознаја субјективног света ограничена на појединца чији је то свет. Другим речима, нико осим човека не може до краја да спозна његов унутрашњи свет. Човек, као суштински субјективно биће, преко различитих облика понашања и активности покушава да осталима пружи увид у тај свет, али све оне стрепње, жеље, сумње, преживљавања, надања, среће, туге, снови и визије, разочарења, духовни падови и узлети, који су флуидни и тешко ухватљиви, сви они су у пуном обиму и интензитету доступни само том појединцу, под условом, наравно, да је он свестан тог свог унутрашњег света, и да не обитава пасивно у њему. Стога се таква човекова окренутост ка унутрашњем животу може рашчланити на два елемента: сопство и метасопство. И док је све оно што одликује сопство у пуној мери субјективно и карактеристично само за тог појединца ${ }^{17}$, дотле је метасопство универзална компонента човекове субјективности, помоћу које он, у крајњем степену, може да разуме другог појединца на најдубљем нивоу, па макар се њихова сопства у пуној мери разликовала. Супротно општем очекивању, које је дубоко утемељено готово у потпуности само у спољашњој равни живљења, апсолутна субјективност и апсолутна универзалност у овом случају „иду руку под руку”. Способност „активне рефлексије” или „делатног сазрцања” дата је сваком човеку само као потенцијал, који се развија стицањем искуства и вежбањем у рефлексији, односно објективном посматрању свога сопства.

${ }^{17}$ У већем или мањем степену може доћи до подударања у садржају сопства са другим појединцима, рекло би се тада да су они на истој или сличној „таласној дужини”, али такав садржај може бити и различит, па и потпуно супротан код две индивидуе и тада најчешће долази до свађа и различитих облика узајамног неразумевања и неприхватања. 
Зато се у античкој Грчкој од оног ко је желео да стекне велику мудрост захтевало да прво спозна самог себе.

С друге стране, човек може размишљати и о спољашњем свету, па се тако његова окренутост ка том свету може рашчланити на елементе: друштво и метадруштво. Елемент друштва састоји се од упознавања закона и односа по којима живи друштво (у крајњој линији у целини, али чешће је код човека да размишља у границама околине у којој обитава), а елемент метадруштва састоји се од рефлексије о тим законима и односима. Крајњи домен рефлексије о спољашњем била би потрага за универзалним истинама Друштва као апстрактног бића, а крајњи домен рефлексије о унутрашњем јесте потрага за универзалним истинама Човека као аnстрактног појединца. За нормалан живот потребно је неговати обе врсте рефлексије, у различитом степену код различитих људи, сходно потребама, темпераменту, склоностима и могућностима, наравно уз одговарајуће радње које прате овакво мишљење, јер без унутрашње рефлексије човек није слободан, а без спољашње рефлексије друштво није здраво. ${ }^{18}$

Однос у коме стоје субјективно сопство и објективно друштво идентичан је односу у ком стоје национално и опште-светско. Без истинског разумевања свог народа, без упознавања његове прошлости, културе, традиције, без свести о његовом менталитету, о његовим манама и врлинама, човек не може у довољној мери да разуме и воли ни један други народ. Порицање важности националног јесте брисање читаве прошлости једног народа, брисање његовог искуства и мудрости, а то може да се уради или из нечије намерне бахатости и прорачунате малициозности (мотивације које се крију иза оваквих поступака немају никакве везе са племенитошћу и алтруизмом, мада се често тако представљају!), или из наивног хуманизма оних који су несвесни последица таквог чина. Неговање националне културе и подстицање других да то исто чине јесте пружање могућности сваком народу да пева својим аутентичним гласом опојну и милозвучну песму у славу живота. Или речима Момчила Настасијевића: „Ништа општечовечанске вредности није постало случајним укрштањем споља.

${ }^{18}$ Није свим људима лако да у потпуности допру до ових истина. Велики мислиоци, теолози, уметници и научници, по правилу су ти који њима највише теже. Овде је важан појам „генија”, јер он је тај коме су ове истине откривене. Стари Грци су разликовали појмове „евгеније” и „какогеније” имајући у свести чињеницу да није довољно да човеку буду откривене универзалне истине, већ и то шта он са њима ради, како служи другима, да ли је своје биће управио ка Добру или ка Злу. Данас се свест о томе да је генијалност мач са две оштрице изгубила под налетом егоцентричности, самољубља и самодовољности, па се комплименти као што су „ти си генијалан” (на страну питање да ли је оцена заиста објективно утемељена) користе у сензационалистичком кључу, а крајња последица тога јесте само потпиривање туђе сујете. 
Кобна је обмана по среди. Свима припадне само ко је кореном дубоко продро у родно тле" (Настасијевић 1991а: 44).

Природно се намеће питање контакта међу народима и њиховим културама. Од огромног су значаја међусобни културни утицаји, а тога смо посебно свесни ми који живимо на шареноликом Балканском полуострву. Ни један народ, или било која ужа културна група, не живе потпуно одвојени од других: културних утицаја је увек било и увек ће их бити и ту нема ничег лошег, напротив, на тај начин се свака култура богати и развија. Оно чега се треба чувати јесте појава коју Настасијевић назива „ропским примањем", а која подразумева потпуно повиновање туђем утицају и прихватање туђе културе и вредносних система, који у суштини нису иманентни сопственој природи. Ово би у најкраћим и најопштијим цртама био покушај сагледавања проблема поделе на „национално” и „опште”, на „модерно” и „традиционално”, на „прогресивно” и „регресивно”, као најширег контекста у ком је ситуирана главна тема овог рада.

Да ли ће друштво и даље наставити да у свом мртвилу, бесциљности и апатији обитава у ништавности и развратности или ће се пренути из кризе, која је у бити духовна, и кренути ка светлости, велико је питање. Тезу да је ово време најгоре од свих до сада, врло лако може да оповргне свако ко иоле добро познаје историју људског друштва. Опасна је варка веровати да је све постало бесмислено и ништавно, и у том очају потпуно превидети оне благодети о којима људи претходних векова нису могли ни да сањају. Потребно је избећи замку лажне дијалектике и истрајати на путу ка Добру. Као и увек, све зависи од појединца, од његове непрестане борбе са самим собом и мраком у себи, од свести о нијансама у значењу, од његове одговорности, објективности, поштења и искрености прво према себи самом, а онда и према другима. Када већина појединаца победи у тој борби и освести оно што је добро и у њима самима и у другима, уз поштовање традиције других, друштво ће кренути у једном хуманијем правцу.

Савремени гуслар, као чувар традиције, филозофије и етике колектива, оних митских, ахретипских слојева људске свести похрањених у корпусу епског наслеђа и одевених у рухо епских јунака и догађаја, налази се пред истим задатком. Била би то једна од могућих фигура идеалног гуслара којој треба да тежи. У сваком случају, савремени гуслар треба да се бори против пародизације традиције оличене у разним видовима, почевши од пуке комерцијализације, па све до потпуног убијања њене суштине. Задатак који је пред њим није лак. Он мора прво сам да уплови у воде епског наслеђа чији чувар и репрезент жели да буде, то наслеђе мора да струји његовим венама, не сме бити површно. Затим мора да се избори са свим 
поменутим баријерама које му савремено друштво, популарна култура и медији постављају. На крају, уколико му је певање уз гусле професија, мора да смисли на који начин да оствари потребну зараду, а да не угрози душу епског певања излажући га опасности од комерцијализације. Савремени гуслар треба да пружи пример осталима - како се вратити животворним коренима, изборити са нихилизмом модерне цивилизације и повратити изгубљени смисао живота. То би била његова главна улога на есенцијалном и егзистенцијалном плану. Из ње проистичу и његова улога и значај у савременом друштву на плану музике, уметности и културе у најширем смислу: савремени гуслар треба да својом уметношћу пружи допринос у постављању високих стандарда и враћању изгубљених вредности.

$$
* * *
$$

Поприлична заступљеност историјског аспекта развоја гусларске извођачке праксе у овом раду, неминовно је узрокована основним циљем самог рада: трагати за узроцима и почецима „одвајања” гусларског извођења од његовог аутентичног извора и на тај начин пронаћи корене проблема у којима се ова пракса, а са њом и гуслар-извођач, данас налазе. Дехуманизујући императив савременог доба креће се у правцу самонегирања, чији је крајњи домен - претварање у сопствену супротност, док се традиционални темељи друштва, почевши од породице, преко образовних институција, а у крајњој линији и читаве културне делатности једног народа, процесом сатанизације изопачују и деформишу до апсурдних граница или се, посредством наратива о нестајању или непостојању, маргинализују и обезвредњују. Гусларска извођачка пракса и гуслар-извођач само су још један пример жртве ове негативне стихије: о њиховој улози и значају пре се може говорити у домену могућности него у домену реалности. Проналажење и објективно анализирање узрока који су довели до овога, а које је рад покушао да осветли, био би први корак у правцу реализације тих могућности. Остаје нада да ће у некој светлијој будућности фигура гуслара заузети истакнуто место у култури и друштву, које јој и припада.

\section{ЛИТЕРАТУРА}

Бодријар 1991: Жан Бодријар, Симболичка размена и смрт, прев. Миодраг Марковић, Дечје новине, Горњи Милановац, 1991.

Варшавер 1991: Gerald E. Warshaver, "On Postmodern Folklore”, in: Western Folklore, 50, July, 1991, pg. 219-229. 
Големовић 2006: Димитрије О. Големовић, Човек као музичко биће, Библиотека XX век, Књижара Круг, Београд, 2006.

Ђорђевић Белић 2013: Смиљана Ж. Ђорђевић Белић, „’Нека је женско, али биће гуслар' - идеологија једног инструмента", у: МУЗИКОЛОГИЈА: часопис Музиколошког института Српске академије наука и уметности, бр. 14, 2013, стр. 159-187.

Ђорђевић Белић 2016: Смиљана Ђорђевић Белић, ПОСТФОЛКЛОРНА ЕПСКА ХРОНИКА: жанр на гранищи и границе жанра, Чигоја штампа, Институт за књижевност и уметност, Београд, 2016.

Ђорђевић Белић 2017: Смиљана Ђорђевић Белић, ФИГУРА ГУСЛАPA: хероизирана биографија и невидљива традиција, Институт за књижевност и уметност, Београд, 2017.

Лајић Михајловић 2014: Данка Лајић Михајловић, Српско традиционално певање уз гусле: гусларска пракса као комуникациони процес, Музиколошки институт САНУ, Београд, 2014.

Лајић Михајловић 2014б: Данка Р. Лајић Михајловић, „Певање епских песама уз гусле са асинхроном сегментацијом музичког и поетског тока", у: Промишьања традииије: фолклорна и литерарна истражсивања, зборник радова посвећен Мирјани Дрндарски и Ненаду Љубинковићу, ур. др Бошко Сувајџић и др Бранко Златковић, Институт за књижевност и уметност, Београд, 2014, стр. 391-406.

Лајић Михајловић, Ђорђевић Белић 2016: Данка Р. Лајић Михајловић, Смиљана Ж. Ђорђевић Белић, „Певање уз гусле и музичка индустрија: гусларска извођења на првим грамофонским плочама (1908-191/2), у: МУЗИКОЛОГИЈА: часопис Музиколошког института Српске академије наука и уметности, бр. 20, 2016, стр. 199-222.

Лајић Михајловић 2006: Данка Лајић Михајловић, „Временска димензија епских песама", у: МУЗИКОЛОГИЈА: часопис Музиколошког института Српске академије наука и уметности, бр. 6, 2006, стр. 343-364.

Лајић Михајловић 2011: Данка Лајић Михајловић, „Такмичења као облик јавне гусларске праксе", у: МУЗИКОЛОГИЈА: часопис Музиколошког института Српске академије наука и уметности, бр. 11, 2011, стр. 183-202.

Лајић Михајловић 2012: Данка Лајић Михајловић, „Учење певања уз гусле у Србији у XXI веку”, у: МУЗИКОЛОГИЈА: часопис Музиколошког института Српске академије наука и уметности, бр. 12, 2012, стр. 121-139.

Лајић Михајловић 2013: Данка Лајић Михајловић, „Реч и музика епске песме - од синкретизма до певане поезије”, у: МУЗИКОЛОГИЈА: 
часопис Музиколошког института Српске академије наука и уметности, бр. 15, 2013, стр. 9-28.

Лорд 1990 I: Albert B. Lord, Реvač priča, prva knjiga: teorija, prev. Slobodanka Glišić, Biblioteka XX vek, Idea, Beograd, 1990.

Наумовић 2009: Slobodan Naumović, Upotreba tradicije u političkom i javnom životu Srbije na kraju dvadesetog i početkom dvadeset prvog veka, Institut za filozofiju i društvenu teoriju, IP „Filip Višnjić” a. d., Beograd, 2009.

Настасијевић 1991a: Момчило Настасијевић, За матерњу мелодију, у: Момчило Настасијевић Есеји, белешке, мисли, прир. Новица Петковић, Сабрана дела Момчила Настасијевића, књига четврта, Дечје новине, СКЗ, Горњи Милановац, 1991, стр. 38-45.

Настасијевић 1991б: Момчило Настасијевић, За хуманизацију музике, у: Момчило Настасијевић Есеји, белешке, мисли, прир. Новица Петковић, Сабрана дела Момчила Настасијевића, књига четврта, Дечје новине, СКЗ, Горњи Милановац, 1991, стр. 80-88.

Настасијевић 1991в: Момчило Настасијевић, Против машинизачије уметности, у: Момчило Настасијевић Есеји, белешке, мисли, прир. Новица Петковић, Сабрана дела Момчила Настасијевића, књига четврта, Дечје новине, СКЗ, Горњи Милановац, 1991, стр. 89-91.

Радовановић 2000: Лазар Ћ. Радовановић, Епска поезија и гусле, 2000.

Сувајџић 2010: Бошко Сувајџић, Певач и традиичја, Завод за уџбенике, Београд, 2010, стр. 175-186.

Đurđina M. Isić

\section{THE FIGURE AND THE SIGNIFICANCE OF THE GUSLAR IN MODERN DAY SOCIETY}

\section{Summary}

The main topic of the paper is the problem of the figure of the guslar in modern day society, that is, its significance and the role it has in public space. Specific changes in the socio-political and cultural paradigm that occured in the twentieth century, also reflected on the epic singing with the gusle. According to a certain group of theorists, they questioned the authenticity of the guslar performing practice as we know it today. Therefore, in order to answer the main problem, first investigation was in the area of development of epic singing with the gusle from the preliteral community to the present moment and all the crucial moments and novelities that they introduced into guslar's performance were noted. The second part of the paper is dedicated to the issue of tradition and cultural 
heritage from a philosophical-anthropological and cultural point of view, but it also deals with the problems of instrumentalization and politicization of tradition (through the prism of Baudrillard's theory of simulacra). In an attempt to answer the question of what is the significance and the role of the guslar in modern day society, the conclusions reached in this research are summarized and some theoretical insight is made - consideration of some of the fundamental problems related to understanding of tradition and its acceptance.

Key words: guslar, gusle, epic singing with the gusle, (epic) tradition, the instrumentalization of tradition, simulacrum, culture, national identity. 